\title{
Parturition in dairy cows temporarily alters the expression of genes in circulating neutrophils
}

\author{
M. A. Crookenden, ${ }^{*} \dagger^{1}$ A. Heiser, $† \ddagger$ A. Murray, $†$ V. S. R. Dukkipati, $†$ J. K. Kay,§ J. J. Loor,\# S. Meier,§ \\ M. D. Mitchell,II K. M. Moyes,ף C. G. Walker, ${ }^{*}$ and J. R. Roche§ \\ *DairyNZ, c/o University of Auckland, Auckland 1010, New Zealand \\ tInstitute of Vet, Animal and Biomedical Sciences, Massey University, Palmerston North 4442, New Zealand \\ $\ddagger$ AgResearch, Hopkirk Research Institute, Palmerston North 4442, New Zealand \\ §DairyNZ, Newstead, Hamilton 3284, New Zealand \\ \#Department of Animal Sciences, University of Illinois, Urbana 61801 \\ ॥University of Queensland, Centre for Clinical Research, Herston, Queensland 4029, Australia \\ IDepartment of Animal and Avian Sciences, University of Maryland, College Park 20742
}

\begin{abstract}
Extensive metabolic and physiologic changes occur during the peripartum, concurrent with a high incidence of infectious disease. Immune dysfunction is a likely contributor to the increased risk of disease at this time. Studies using high-yielding, total mixed ration-fed cows have indicated that neutrophil function is perturbed over the transition period; however, this reported dysfunction has yet to be investigated in moderate-yielding, grazing dairy cows. Therefore, we investigated changes in the expression of genes involved in neutrophil function. Blood was collected from cows at 5 time points over the transition period: precalving $(-1 \mathrm{wk} ; \mathrm{n}=46)$, day of calving $(\mathrm{d} 0 ; \mathrm{n}=46)$, and postcalving at wk $1(\mathrm{n}=46)$, wk $2(\mathrm{n}=45)$, and wk $4(\mathrm{n}=43)$. Neutrophils were isolated by differential centrifugation and gene expression was investigated. Quantitative reverse transcriptase PCR with customdesigned primer pairs and Roche Universal Probe Library (Roche, Basel, Switzerland) chemistry, combined with microfluidics integrated fluidic circuit chips (96.96 Dynamic Array, San Francisco, CA) were used to investigate the expression of 78 genes involved in neutrophil function and 18 endogenous control genes. Statistical significance between time points was determined using a repeated measures ANOVA. Genes that were differentially expressed over the transition period included those involved in neutrophil adhesion (SELL, ITGB2, and ITGBX), mediation of the immune response (TLR4, HLA-DRA, and CXCR2), maturation, cell cycle progression, apoptosis (MCL1, BCL2,
\end{abstract}

Received January 9, 2016.

Accepted April 2, 2016.

${ }^{1}$ Corresponding author: mallory.crookenden@dairynz.co.nz
FASLG, and RIPK1), and control of gene expression (PPARG, PPARD, and STAT3). We noted reduced gene expression of proinflammatory cytokines (IFNG, TNF, IL12, and CCL2) on the day of calving, whereas anti-inflammatory cytokine gene expression (IL10) was upregulated. Increased gene expression of antimicrobial peptides (BNBD4, DEFB10, and DEFB1) occurred on the day of calving. Collectively, transcription profiles are indicative of functional changes in neutrophils of grazing dairy cows over the transition period and align with studies in cows of conventional total mixed ration systems. This altered function may predispose cows to disease over the transition period and is likely to be a natural change in function due to parturition.

Key words: PMN, Fluidigm, peripartum period, innate immune function

\section{INTRODUCTION}

The transition period in a dairy cow is a critical period of metabolic and physiologic change encompassing parturition and the onset of lactogenesis (Grummer, 1995). A considerable alteration in nutrient and metabolic demand is associated with an increased susceptibility to metabolic and infectious disease conditions during the peripartum period (Overton and Waldron, 2004; Ingvartsen, 2006). For example, the incidence of intramammary infections is increased in the $4 \mathrm{wk}$ immediately postcalving both in TMR- (Østergaard et al., 2005) and pasture-based dairy systems (Compton et al., 2007). An estimated 30 to $50 \%$ of cows are reported to experience health disorders during the transition period, and the majority (75\%) of infectious disease and metabolic disorders in dairy cows occur during this time (Ingvartsen, 2006; LeBlanc et al., 2006). In pasture-based systems an estimated NZD $\$ 300$ per cow 
is lost annually due to costs associated with transition failure (i.e., cows that experience health disorders; Compton et al., 2007; Roche, 2014).

Previous studies have indicated that the high incidence of disease during the transition period is linked to a state of reduced immune function (Detilleux et al., 1995; Goff and Horst, 1997; Heiser et al., 2015). In these investigations, neutrophils have received much attention due to their essential role in defense against pathogens responsible for mastitis and uterine infections (Madsen et al., 2004; Hammon and Goff, 2006; Graugnard et al., 2012). Functional studies at the cellular level have indicated neutrophil dysfunction during the peripartum period; for example, studies have shown reduced superoxide production, phagocytosis, expression of cell surface adhesion molecules, and capacity for migration (Kehrli et al., 1989; Burton et al., 1995, 2005). Consequently, there is reduced efficiency of the neutrophil inflammatory response, thereby contributing to greater incidence of infection. The extent of this peripartum neutrophil dysfunction has not been fully elucidated.

Furthermore, the studies referred to were all undertaken using high-yielding, housed cows. However, milk production is 30 to $50 \%$ less in pasture-based systems (Kolver and Muller, 1998), the population density on farm is lower, different management systems may alter pathogen load, and the infectious disease-causing pathogens may differ. Therefore, we hypothesized that the changes in peripartum neutrophil function will be different in grazing dairy cows in the absence of stimulation. To investigate this, neutrophils were extracted over the transition period from moderate-yielding, grazing dairy cows and the expression of 78 genes involved in neutrophil function were investigated.

\section{MATERIALS AND METHODS}

\section{Animal Handling}

The Ruakura Animal Ethics Committee (Hamilton, New Zealand) approved all animal manipulations in accordance with the New Zealand Animal Welfare Act (Ministry of Primary Industries, 1999). The experiment was undertaken at Scott Farm, Hamilton, New Zealand $\left(37^{\circ} 46^{\prime} \mathrm{S}, 175^{\circ} 18^{\prime} \mathrm{E}\right)$, between July and October 2013.

\section{Experimental Design and Treatments}

A subset of cows of mixed age and breed (HolsteinFriesian, Jersey, and Holstein-Friesian $\times$ Jersey) were selected from a parent experiment, described in detail by Roche et al. (2015). Cows were 1 of 2 precalving BCS categories (4.0 or 5.0; based on a 10-point scale; Roche et al., 2004) and 1 of 2 levels of energy intake preceding calving ( 75 or $125 \%$ of estimated requirements). Blood was sampled by coccygeal venipuncture at 5 time points over the transition period: 1 wk before estimated calving date $(-1 \mathrm{wk} ; \mathrm{n}=46)$, day of calving (d $0 ; \mathrm{n}$ $=46)$, d 7 (1 wk; n = 46), d 14 (2 wk; $\mathrm{n}=45)$, and d 28 (4 wk; $\mathrm{n}=43$ ) postcalving. Blood for neutrophil isolation (total of $36 \mathrm{~mL}$ per cow at each time point) was collected in 6 evacuated blood tubes (Vacutainer; BD Bioscience, Plymouth, UK) containing acid citrate dextrose (solution $\mathrm{b} ; 22.0 \mathrm{~g} / \mathrm{L}$ of trisodium citrate, 8.0 $\mathrm{g} / \mathrm{L}$ of citric acid, $24.5 \mathrm{~g} / \mathrm{L}$ of dextrose). Blood tubes were inverted 8 times and placed immediately on ice awaiting neutrophil isolation by differential centrifugation based on protocols (Osorio et al., 2013; Moyes et al., 2014), with modifications described herein. Blood for metabolite analysis was collected in evacuated blood tubes containing a lithium heparin anticoagulant, inverted, and placed immediately on ice; within $30 \mathrm{~min}$, blood tubes were centrifuged at $1,500 \times g$ for $12 \mathrm{~min}$ at $4^{\circ} \mathrm{C}$, plasma aspirated, and stored at $-20^{\circ} \mathrm{C}$ until assayed.

\section{Liver Sampling for Triacylglycerol Analysis}

Liver samples were collected from all cows by biopsy the week before calving ( $\mathrm{wk}-1$ ), and subsequently on wk 1, 2, and 4 postcalving. Briefly, the skin was shaved and disinfected and the area anesthetized with $7 \mathrm{~mL}$ of $2 \%$ lignocaine (Lopaine 2\%, lignocaine hydrochloride $20 \mathrm{mg} / \mathrm{mL}$, Ethical Agents, South Auckland, New Zealand). An incision was made through the skin in the right 11th intercostal space at the level of the greater trochanter, through which a 12-gauge $\times 20$-cm biopsy needle was inserted into the liver and approximately $1 \mathrm{~g}$ (wet weight) of liver tissue was collected. Liver samples were snap-frozen in liquid nitrogen and stored at $-80^{\circ} \mathrm{C}$.

\section{Neutrophil Isolation}

Neutrophils were isolated according to procedures previously described (Moyes et al., 2010a; Osorio et al., 2013) with modifications. Blood collected in the 6 acid citrate dextrose evacuated blood tubes were inverted and pooled by transfer into a $50-\mathrm{mL}$ conical tube. Tubes were centrifuged for $30 \mathrm{~min}$ at $850 \times \mathrm{g}$ at $4^{\circ} \mathrm{C}$. The plasma, buffy coat, and up to one-third of the red blood cells were aspirated by pasture pipette and discarded, leaving two-thirds of red blood cells and neutrophils remaining. Water (milliQ, Millipore, Billerica, MA) was added $(25 \mathrm{~mL})$ and mixed for 10 to $30 \mathrm{~s}$ to lyse the red blood cells, and $5 \mathrm{~mL}$ of $5 \times$ concentrated PBS (pH 7.4, Life Technologies, Carlsbad, CA) was added to each 
tube to restore isotonicity. Tubes were spun at $330 \times g$ for $10 \mathrm{~min}$ at $4^{\circ} \mathrm{C}$ and supernatant decanted to isolate the white cell pellet. The pellet was washed with 10 $\mathrm{mL}$ of $1 \times$ concentrated PBS (pH 7.4, Life Technologies), vortexed, and centrifuged for $5 \mathrm{~min}$ at $660 \times g$ at $4^{\circ} \mathrm{C}$. If red blood cells remained, the water-lysing step was repeated. Cells were resuspended in $5 \mathrm{~mL}$ of $1 \times$ PBS (pH 7.4) and $100 \mu \mathrm{L}$ was transferred to a $1.5-\mathrm{mL}$ microcentrifuge tube (Raylab, Auckland, New Zealand) and placed on ice for subsequent viability and staining assays. The $50-\mathrm{mL}$ tubes were centrifuged again ( $5 \mathrm{~min}$ at $660 \times g$ at $\left.4^{\circ} \mathrm{C}\right)$, liquid decanted, and the cell pellet resuspended in $1 \mathrm{~mL}$ of TRIzol reagent (Life Technologies). The 1-mL cell suspension was transferred to a 2-mL microcentrifuge tube (Eppendorf, Hamburg, Germany), placed immediately on ice, and stored at $-80^{\circ} \mathrm{C}$ for subsequent RNA extraction.

\section{Flow Cytometry Analysis}

A subpopulation of isolated cells from randomly selected samples $(\mathrm{n}=41)$ was used to determine cell viability and neutrophil population by flow cytometry analysis (Figure 1) using the BD FACS Aria II cell sorter (BD Biosciences, San Jose, CA). Viability was measured using LIVE/DEAD Fixable Blue Dead Cell Stain Kit (L23105, Life Technologies), and neutrophil populations were determined with the bovine granulocyte-specific primary monoclonal antibody CH138A (WS0608B-100, Kingfisher Biotech Inc., St. Paul, MN) and phycoerythrin-conjugated secondary antibody (SB102009S, Southern Biotech, Birmingham, AL). Of all the granulocytes isolated (78.6 $\pm 14.4 \%$; median \pm $\mathrm{SD})$ with this procedure, $93.4 \pm 7.9 \%($ mean $\pm \mathrm{SD})$ were neutrophils and, of these, $93.3 \pm 10.2 \%$ (mean \pm $\mathrm{SD})$ were live cells.

\section{RNA Extraction}

Total RNA was extracted from neutrophils ( $\mathrm{n}=$ 226) using TRIzol reagent as per the manufacturers' instructions. Briefly, cell suspensions in TRIzol were homogenized using a PRO200 homogenizer (Pro Scientific, Oxford, CT); suspensions underwent two 20-s bursts of the homogenizer at full speed $(500 \mathrm{~Hz})$ and were placed on ice after every homogenization. The homogenizer tool was rinsed twice with $75 \%$ ethanol and water, and once with RNaseZap (Life Technologies) between each sample. Chloroform was added to the homogenized samples and, after centrifugation, the aqueous phase was carefully removed. Precipitation of RNA was achieved with the addition of isopropanol (Merck Millipore, Billerica, MA) and the subsequent RNA pellet was washed (with $75 \%$ ethanol), dried, and resuspended in UltraPure RNase/DNase-free distilled water (Life Technologies). All RNA samples were DNase treated using the Ambion DNA-free kit (Life Technologies). The quantity of RNA was determined by spectrophotometry using a Nanodrop ND-1000 (Nanodrop Technologies, Wilmington, DE) and RNA integrity was confirmed using an Agilent 2100 Bioanalyzer and RNA 6000 Nano LabChip kit (Agilent Technologies, Santa Clara, CA). Samples had an average RNA integrity number $( \pm \mathrm{SD})$ of $8.0 \pm 0.77$. Samples were stored at $-80^{\circ} \mathrm{C}$ until cDNA synthesis.

\section{cDNA Synthesis and Primer Design}

Total RNA $(2 \mu \mathrm{g})$ from each sample was reverse transcribed using a Superscript III Supermix kit (Life Technologies) with random pentadecamer primers [Integrated DNA Technologies (IDT), Singapore] at a final concentration of $27 \mu \mathrm{M}$. Reverse-transcriptase negative controls were also generated by excluding the enzyme, and cDNA samples were stored at $-20^{\circ} \mathrm{C}$.

Assay design for 96 gene targets $(78$ genes involved in neutrophil function and 18 possible endogenous control genes identified using current literature, Supplemental Table S1; http://dx.doi.org/10.3168/jds.2015-10877) for use in reverse transcription-quantitative PCR (RTqPCR) was undertaken using publicly available bovine gene sequences from the National Center for Biotechnology Information gene database (http://www.ncbi.nlm. nih.gov). Assays were designed to span an intron-exon boundary, where possible, using Roche Universal Probe Library (UPL; Roche, Basel, Switzerland) design software. Primer sequences were verified by BLAST and PrimerBLAST analysis (http://www.ncbi.nlm.nih.gov/ tools/primer-blast/) to ensure specificity. Assays were tested on a LightCycler 480 instrument (Roche). Each RT-qPCR reaction contained custom designed forward and reverse primers (200 n $M$, IDT), UPL unique probe (50 nM, Roche), LightCycler 480 Probes Master $(2 \times$ concentration), and RNase/DNase-free distilled water. Standard cycling conditions were used $\left[95^{\circ} \mathrm{C}\right.$ for $10 \mathrm{~min}$ $\left(95^{\circ} \mathrm{C}\right.$ for $10 \mathrm{~s}, 60^{\circ} \mathrm{C}$ for $\left.30 \mathrm{~s}\right) \times 50$ cycles, $40^{\circ} \mathrm{C}$ for $40 \mathrm{~s}$. To test assays, a 6-point, 10-fold standard curve was generated starting at $1 \times$ dilution (1:4 dilution of raw cDNA) to $1 \times 10^{-6}$ dilution. Positive and negative samples were verified with gel electrophoresis to ensure a single product free of genomic DNA contamination and to verify the amplicon size.

\section{Gene Expression}

Expression of genes involved in neutrophil function was assayed using RT-qPCR using the BioMark HD real-time PCR system (Ramaciotti Centre, University 
of New South Wales, Randwick, Australia). Microfluidics 96.96 Dynamic Array (Fluidigm, San Francisco, CA) integrated fluidic circuit chips combined with Roche UPL chemistry were used to generate expression results for 96 gene targets for all samples $(n=226)$. A preamplification of cDNA was undertaken to create specific target amplified reactions by multiplexing forward and reverse primers $(200 \mathrm{n} M)$ of the 96 assays with $5 \times$ concentration PreAmp Master Mix (Fluidigm) and the following cycling protocol: $95^{\circ} \mathrm{C}$ for $10 \mathrm{~min}$ $\left(95^{\circ} \mathrm{C}\right.$ for $15 \mathrm{~s}$, and $60^{\circ} \mathrm{C}$ for $\left.4 \mathrm{~min}\right) \times 14$ cycles. Assay mixtures, including forward and reverse primers $(800$ $\mathrm{n} M)$, Roche UPL probes (100 $\mathrm{n} M$ ), and $2 \times$ concentration assay loading reagent (Fluidigm) were combined with $2 \times$ concentration Roche LightCycler 480 Probes Master (Roche) and $20 \times$ gene expression sample load-
(A)

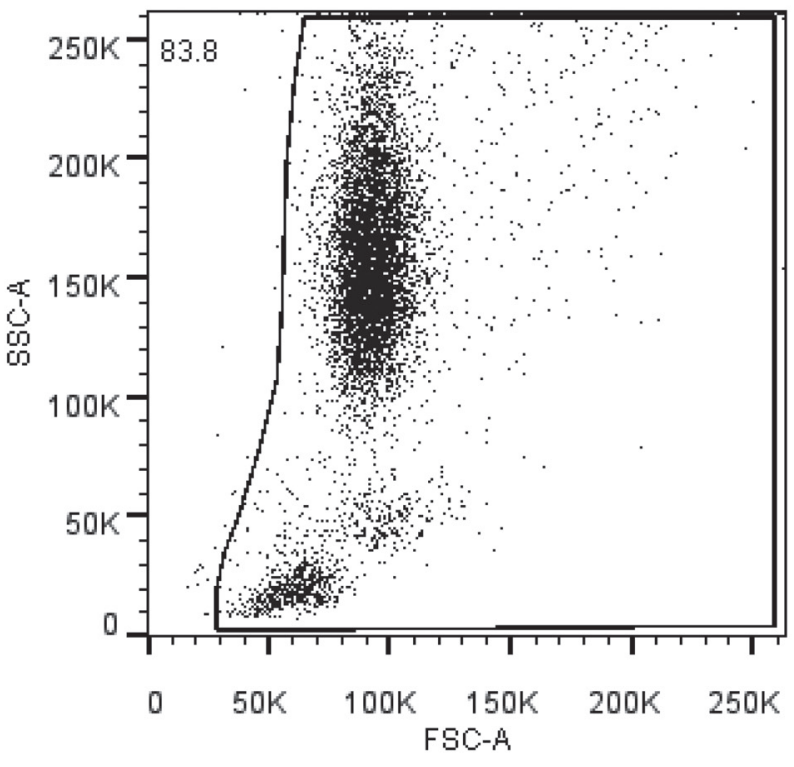

(B)

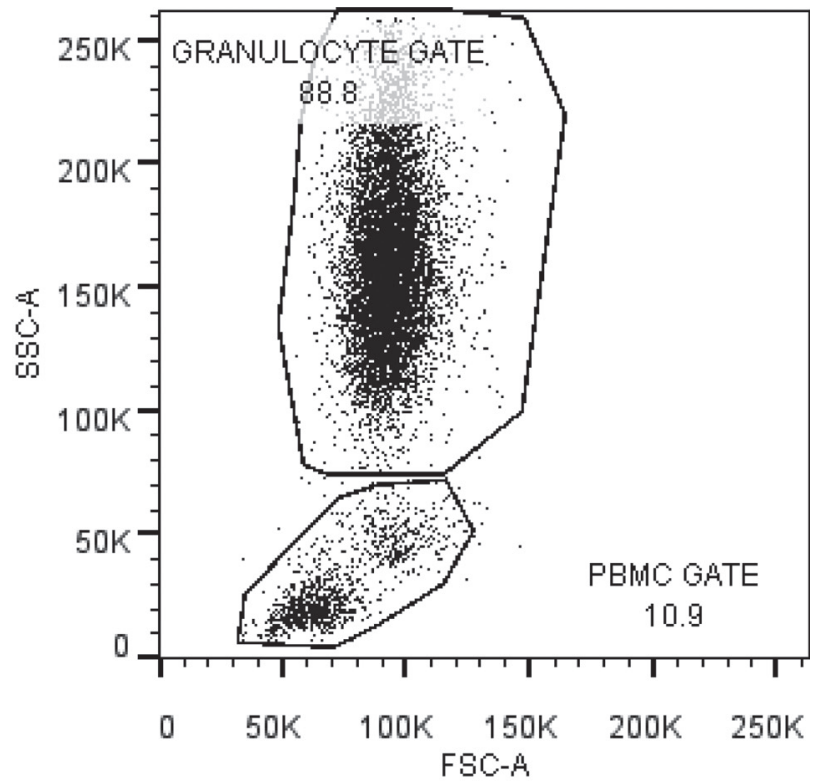

(C)

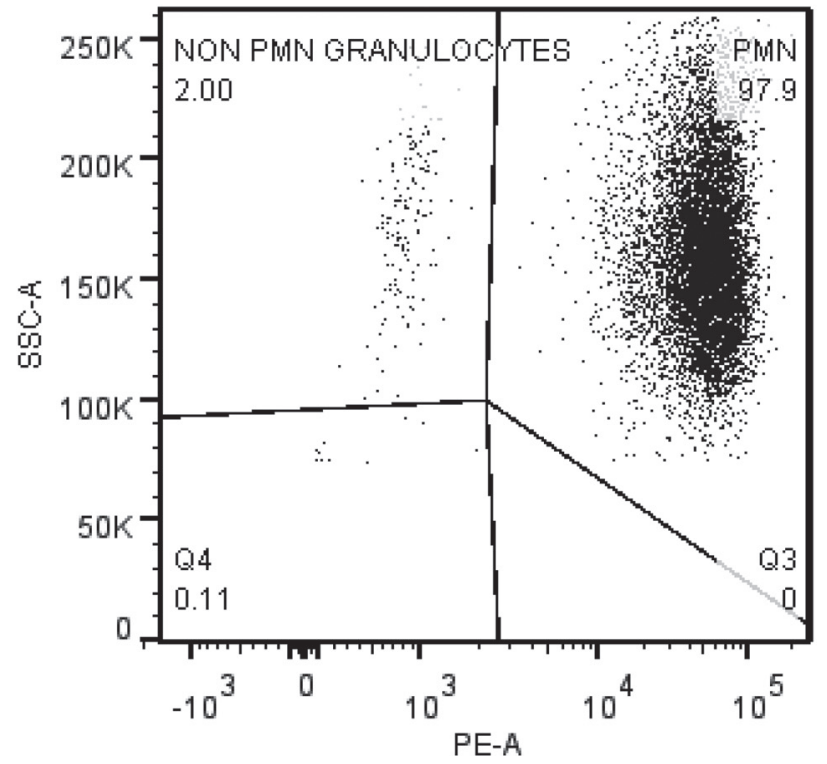

Figure 1. Flow cytometric pictures demonstrating gating strategy of representative sample after neutrophil isolation protocol. (A) Initial gating removes counts that are sitting on the edges of the flow cytometry parameters. Counts were plotted by forward scatter-area (FSC-A) and FSC-height (FSC-H) to remove doublets (data not shown). (B) Gating strategy to identify population of granulocytes from peripheral blood mononuclear cells (PBMC) based on side scatter-area (SSC-A) and FSC-A. (C) Of the total granulocytes isolated, neutrophils (quadrant 2; PMN) could be distinguished from non-neutrophil granulocytes (quadrant 1; non-PMN granulocytes) based on CH138A-phycoerythrin (PE) fluorescence. 
ing reagent (Fluidigm) on a 96.96 gene expression chip (Fluidigm) for use in the BioMark HD instrument. The gene expression thermal cycling protocol "GE $96 \times 96$ UPL v1.pcl" (Biomark HD Data Collection software v3.0.2), $70^{\circ} \mathrm{C}$ for $30 \mathrm{~min}, 25^{\circ} \mathrm{C}$ for $10 \mathrm{~min}, 95^{\circ} \mathrm{C}$ for 1 min, followed by 35 cycles of $96^{\circ} \mathrm{C}$ for $5 \mathrm{~s}$, and $60^{\circ} \mathrm{C}$ for 20 s, was used to generate crossing point $(\mathbf{C p})$ values.

Possible endogenous control genes were tested across all samples using GeNorm (Vandesompele et al., 2002) and NormFinder (Andersen et al., 2004) software. A 5 -point standard curve was included (3-fold serial dilutions from $3.33 \times 10^{-1}$ to a final dilution of $4.12 \times$ $10^{-3}$ ) to calculate RT-qPCR efficiency of all 96 genes. Eighteen potential endogenous control genes were included in the experiment. Of the 18 endogenous control genes tested, RPL19 and YWHAZ were chosen as the 2 endogenous control genes for this neutrophil study. The NormFinder stability of the combination of these 2 genes was 0.072 and the GeNorm stability values were $<0.58$ for both genes, with no improvement in stability with the addition of a third endogenous control gene.

Relative quantification was achieved using the delta $\mathrm{Cp}$ method; the geometric mean of the $\mathrm{Cp}$ values of the endogenous control genes were calculated and the target assay $\mathrm{Cp}$ values were made relative to the geometric mean of endogenous controls $(\Delta \mathrm{Cp})$. The fold change relative to the day of calving ( $\Delta \Delta \mathrm{Cp}$; data not shown) can be calculated as shown in equation [1]:

$$
\Delta \Delta \mathrm{Cp}=\mathrm{E}_{\text {gene of interest }}{ }^{-(\Delta \mathrm{Cp} \text { time point }-\Delta \mathrm{Cp} \mathrm{d} 0)},
$$

where $\mathrm{E}$ is the efficiency of the RT-qPCR reaction (Supplementary Table S1; http://dx.doi.org/10.3168/ jds.2015-10877) calculated using the slope of the standard curve generated by RT-qPCR and the Fluidigm Real-Time PCR Analysis software.

\section{Metabolite Analysis}

Blood metabolite and the liver triacylglycerol (TAG) assays were undertaken by Gribbles Veterinary Pathology Ltd. (Hamilton, New Zealand). Full details of blood metabolite analysis are described in Roche et al. (2015). Briefly, blood metabolites were assayed using colorimetric techniques at $37^{\circ} \mathrm{C}$ with a Hitachi Modular P800 analyzer (Roche). Roche reagent kits were used to measure plasma concentrations of albumin $(\mathrm{g} / \mathrm{L})$, BHB (mmol/L), Ca $(\mathrm{mmol} / \mathrm{L}), \mathrm{Mg}(\mathrm{mmol} / \mathrm{L})$, and total protein $(\mathrm{g} / \mathrm{L})$. Plasma globulin was calculated as the difference between total protein and albumin. Plasma nonesterified fatty acid (NEFA) concentrations $(\mathrm{mmol} / \mathrm{L})$ were measured using WAKO Chemicals (Osaka, Japan) kit. Interleukins (IL-1 $\beta$ and IL-6) and haptoglobin were analyzed by commercial bovine
ELISA kits (Pierce, Thermo Scientific, Waltham, MA, and GenWay Biotech Inc., San Diego, CA, and Life Diagnostics Inc., West Chester, PA). Cholesterol and total antioxidant capacity (TAC) were also measured through commercially available kits (10007640 and 709001 respectively, Cayman Chemical Company, Ann Arbor, MI). Reactive oxygen species (ROS) were measured through a commercially available fluorimetric kit (STA-342, Cell Biolabs Inc., San Diego, CA). Liver TAG content was analyzed in biopsy samples (wk 1, 2, and 4 postcalving) using the standard procedure provided in the Wako LabAssay TM Triglyceride Kit (290-63701, Wako Chemicals USA Inc., Richmond, VA).

\section{Statistics}

All variables (gene expression, metabolites, and production) were subjected to repeated measures ANOVA to assess the effect of time, using a mixed models approach (Proc Mixed, SAS 9.3, SAS Institute Inc., Cary, $\mathrm{NC}$ ) that included the fixed effects of treatment in the parent experiment, week, and their interaction, with cow as a random effect. The model for gene expression also included the Fluidigm chip as a blocking factor, whereas the models for metabolites and production, where possible, included covariate data from the previous lactation. Metabolite data including BHB, NEFA, aspartate transaminase (AST), haptoglobin, IL-1 $\beta$, IL-6, and ROS were $\log _{10}$ transformed to achieve homogeneity of variance. If the effect of time was significant $(P<0.05)$, Tukey's $t$-test was used for pairwise comparisons among weeks. Statistical significance was considered $P \leq 0.05$ and a trend was considered when $P \leq 0.10$. Results are presented as least squares means with standard error of the difference.

\section{RESULTS}

The expression of genes involved in neutrophil function across the transition period is presented in Table 1. Genes are grouped into functional pathways and presented in alphabetical order within those groups. Relative expression $(\Delta \mathrm{Cp})$ at each time point is presented, along with standard error of the difference and significance of time effect ( $P$-value). Genes that were not significantly $(P \geq 0.05)$ altered by time were $C C L 3$, CXCR 4, IL8, TRAF6, CD14, FCGR1A, TAP, CPNE3, IAP, CDC42, DAXX, NFKB, PPARA, and ABCA1 (data not shown).

\section{Expression of Genes Involved in the Inflammatory Response}

Gene expression of proinflammatory cytokines IFNG, $T N F$, and IL23A and the chemokine CCL2 were down- 
Table 1. Expression of genes involved in neutrophil function that changed significantly $(P<0.05)$ over the transition period ${ }^{1}$

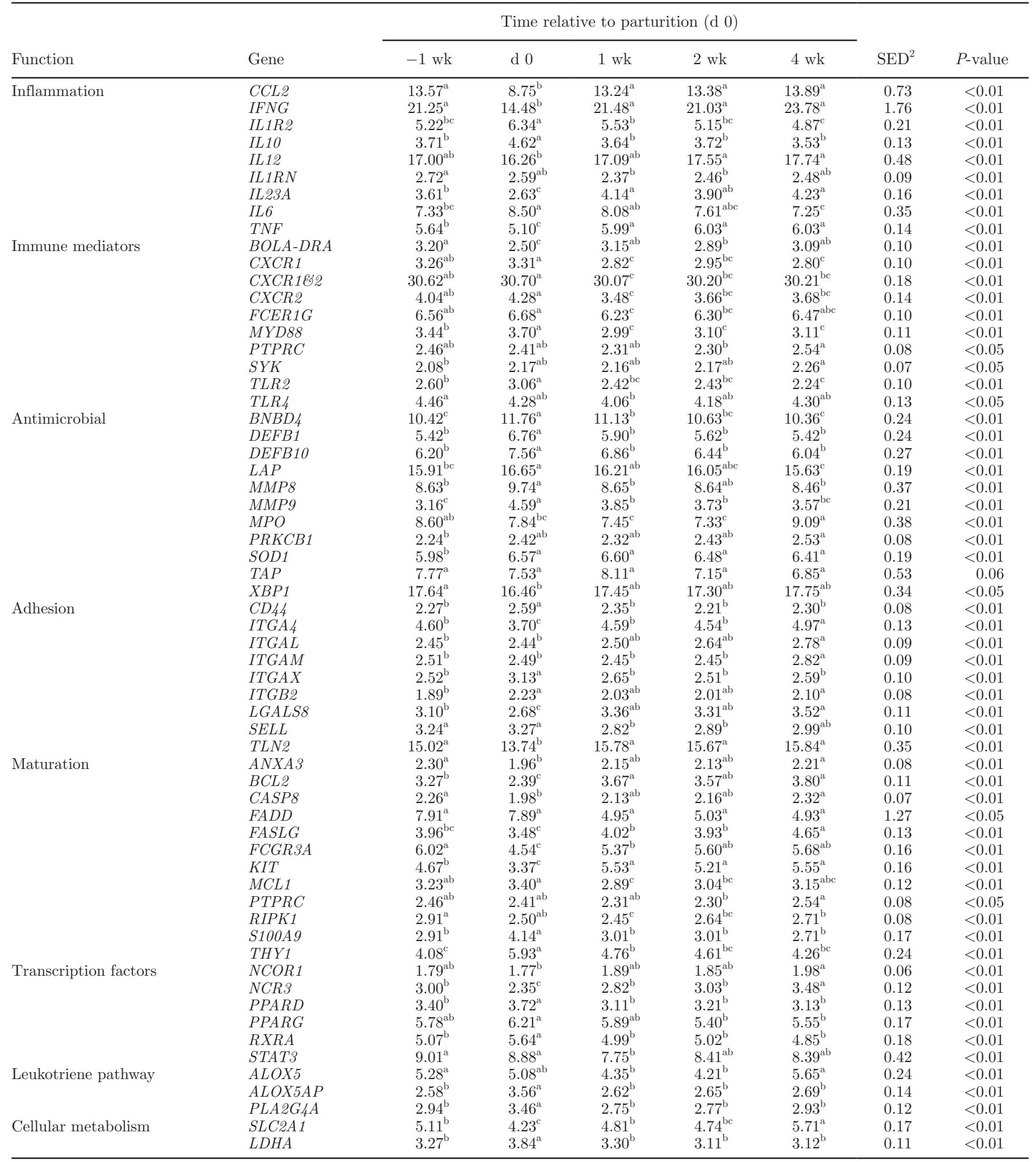

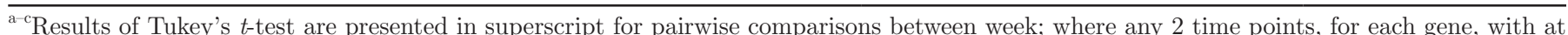
least 1 common letter do not differ significantly $(P>0.05)$ and those without at least 1 common letter differ significantly $(P<0.05)$.

${ }^{1}$ Expression is presented as means over time in arbitrary units normalized to 2 endogenous control genes (RPL19 and YWHAZ; $\left.\triangle \mathrm{Cp}\right)$.

${ }^{2} \mathrm{SED}=$ standard error of the difference. 
regulated $(P \leq 0.05)$ on the day of calving compared with all other time points, and IL12 was downregulated at calving compared with 2 and 4 wk postcalving. Consistent with this, we noted increased gene expression of cytokines IL10, an anti-inflammatory cytokine (Saraiva and O'Garra, 2010) and IL6, which can act as an anti-inflammatory cytokine during acute inflammation (Xing et al., 1998). Gene expression of $I L 8$ in neutrophils was not altered over the transition period (data not shown). Transcript abundance of IL8 receptors however (CXCR1 and CXCR2) were downregulated postcalving compared with -1 wk and the day of calving. Expression of the gene encoding the major histocompatibility complex (MHC) class II molecule $B O L A-D R A$ decreased on the day of calving compared with all other time points. We observed no significant $(P=0.18)$ changes in the expression of $C X C R 4$ over the transition period.

\section{Toll-Like Receptor Signaling}

Expression of genes involved in toll-like receptor (TLR) signaling, including TLR2, TLR4, XBP1, TRAF6, and $M Y D 88$, declined after calving relative to precalving expression levels. For example, gene expression of XBP1 and TLR 4 was greater before calving than on the day of calving and 1 wk postcalving, respectively $(P<0.05)$. Similarly, TLR2 and MYD88 gene expression was greater on the day of calving compared with postcalving time points. However, TLR signaling genes TRAF6 and CD14 were not differentially expressed over the transition period.

\section{Expression of Genes Involved in Antimicrobial Function of Neutrophils}

Expression of antimicrobial peptide genes $B N B D 4$, $D E F B 1$, and DEFB10 was upregulated $(P<0.05)$ on the day of calving, compared with pre- and postcalving time points. Likewise, $L A P$ gene expression was greater $(P<0.01)$ on the day of calving compared with precalving and 4 wk postcalving. We noted a tendency $(P=0.06)$ for the gene expression of TAP to change with time, with a 1.5 -fold increase at $1 \mathrm{wk}$ postcalving compared with the day of calving. Expression of other microbicidal genes, $M P O$ and $S O D 1$, were also differentially expressed over the transition period; SOD1 gene expression was lowest at $-1 \mathrm{wk}$, increased on the day of calving, and remained elevated across the 4 -wk measurement period. In comparison, expression of $M P O$ was 2.0 -fold less on the day of calving $(P<0.05)$ before returning to precalving expression levels at $4 \mathrm{wk}$.

Expression of matrix metalloproteinase genes $M M P 8$ and $M M P 9$ was upregulated on the day of calving com- pared with all other time points. Expression of both transcripts decreased immediately postcalving; however, transcript abundance of $M M P 9$ remained above precalving levels at 1 (1.6-fold) and 2 wk (1.5-fold) postcalving $(P<0.05)$.

\section{Expression of Genes Involved in Attachment and Extravasation}

Expression of the SELL gene was downregulated $(P<0.05)$ at all time points postcalving relative to precalving and the day of calving. Relative gene expression of the integrins across the transition period was dependent on the integrin considered; ITGAL and ITGAM remained stable throughout the immediate calving period, but expression was greater $(P<0.01)$ at wk 4 postcalving. The abundance of transcripts for the ITGAX and ITGB2 integrins and $C D 44$ was greater $(P<0.05)$ on the day of calving compared with most other time points, whereas ITGA4 integrin and extracellular matrix adhesion proteins LGALS8 and TLN2 were downregulated on the day of calving and exhibited greatest expression at wk 4 postcalving. We noted no change in the gene expression levels of IAP and CPNE3 across the time points considered.

\section{Neutrophil Maturation and Cell Cycle}

Several genes involved in the regulation of apoptosis were differentially expressed over the transition period. Gene expression of FASLG, BCL2, and KIT was decreased on the day of calving compared with all other time points. Furthermore, $C A S P 8$ gene expression was also lower on the day of calving compared with 1 wk precalving and 4 wk postcalving. Gene expression of RIPK1, FCGR $3 A$, and ANXA3 was lower on the day of calving compared with precalving levels. Gene expression of RIPK1 remained low for all postcalving time points $(P<0.05)$, whereas gene expression of both FCGR $3 A$ and ANXA3 recovered within the first week postcalving. Gene expression of $M C L 1$ was greater on the day of calving, compared with wk 1 and 2 postcalving. Other genes involved in cell differentiation, including S100A9 and THY1, had increased gene expression on the day of calving compared with all other time points.

\section{Expression of Transcription Factors}

The gene expression of the transcription factors $P P A R D$ and $R X R A$ was greater on the day of calving compared with all other time points $(P<0.05)$. Gene expression of the other transcription factors investigated (NCOR1, NCR3, PPARG, and STAT3) changed 
Table 2. Production results over transition period; results are presented as LSM with standard error of the difference (SED) and significance of week ( $P$-value)

\begin{tabular}{|c|c|c|c|c|c|}
\hline \multirow[b]{2}{*}{ Parameter } & \multicolumn{3}{|c|}{ Time relative to parturition $(\mathrm{d} 0)$} & \multirow[b]{2}{*}{ SED } & \multirow{2}{*}{$\begin{array}{c}P \text {-value } \\
\text { Week }\end{array}$} \\
\hline & $\begin{array}{l}\text { d } 0-7 \\
(1 \text { wk) }\end{array}$ & $\begin{array}{l}\text { d 8-14 } \\
(2 \text { wk) }\end{array}$ & $\begin{array}{l}\text { d } 21-28 \\
(4 \mathrm{wk})\end{array}$ & & \\
\hline $\begin{array}{l}\text { Milk weight, } \mathrm{kg} \\
\text { Composition, \% }\end{array}$ & $21.15^{\mathrm{c}}$ & $22.31^{\mathrm{b}}$ & $24.16^{\mathrm{a}}$ & 0.28 & $<0.01$ \\
\hline Fat & $5.13^{\mathrm{a}}$ & $4.7^{\mathrm{b}}$ & $4.22^{\mathrm{c}}$ & 0.11 & $<0.01$ \\
\hline Protein & $4.15^{\mathrm{a}}$ & $3.62^{\mathrm{b}}$ & $3.33^{\mathrm{c}}$ & 0.05 & $<0.01$ \\
\hline Lactose & $4.69^{\mathrm{b}}$ & $4.82^{\mathrm{a}}$ & $4.83^{\mathrm{a}}$ & 0.09 & $<0.01$ \\
\hline \multicolumn{6}{|l|}{ Yield, kg/d } \\
\hline Fat & 1.1 & 1.06 & 1.02 & 0.03 & 0.08 \\
\hline Protein & $0.89^{\mathrm{a}}$ & $0.81^{\mathrm{b}}$ & $0.80^{\mathrm{b}}$ & 0.02 & $<0.01$ \\
\hline $\log _{10}$ SCC & $5.09^{\mathrm{a}}$ & $4.91^{\mathrm{a}}$ & $4.67^{\mathrm{b}}$ & 0.08 & $<0.01$ \\
\hline
\end{tabular}

${ }^{\mathrm{a}-\mathrm{c}}$ Results of Tukey's $t$-test are presented in superscript for pairwise comparisons between week; where any 2 wk, for each parameter, with at least 1 common letter do not differ significantly $(P>0.05)$ and those without at least 1 common letter differ significantly $(P<0.05)$.

with time but did not have any consistent expression changes. We found no significant effects of week on gene expression of NFKB1 and PPARA.

\section{Cholesterol Transport, Leukotrienes, Glucose Transport, and Glycolysis}

Expression of genes involved in cholesterol transport and leukotriene synthesis was generally lower postcalving compared with precalving or the day of calving. For example, transcript abundance of PLA2G4A and $A L$ $O X 5 A P$ was greater on the day of calving relative to all other time points, whereas precalving $A L O X 5$ exceeded that at 1 (1.8-fold) and 2 wk (2.1-fold) postcalving and returned to precalving levels at 4 wk. We observed no significant alteration in $A B C A 1$ gene expression over the calving period.

Gene expression of SLC2A1 (encoding the glucose transporter GLUT1) was decreased on the day of calving compared with most other time points, and the expression was greatest at 4 wk postcalving (2.8 foldgreater than d 0). Abundance of $L D H A$ was greater on the day of calving compared with all other time points $(P<0.05)$.

\section{Milk Production and Metabolic Data}

Milk yield increased from wk 1 to 4 , but fat and protein percent declined (Table 2). As a result, fat and protein yields were not affected by time. The profile of changes in metabolite data over the transition period is presented in Table 3. All metabolites changed with time $(P<0.05)$. Total protein was greater $(P<0.05)$ on the day of calving and at 4 wk postcalving compared with other time points. Albumin also increased on the day of calving, and globulin concentrations varied over the transition period; however, an increase in plasma globulin at $4 \mathrm{wk}$ postcalving resulted in a decreased albumin-to-globulin ratio at this time point. Liver TAG, AST, and IL-6 concentrations were lowest precalving and increased postcalving. Haptoglobin increased at calving, with variable concentrations postcalving. Blood cholesterol concentrations were elevated at 4 wk postcalving compared with other postcalving time points.

\section{DISCUSSION}

The presented results provide evidence of altered gene expression signatures in the neutrophils from moderateyielding dairy cows grazing fresh pasture immediately before and after parturition. Results are consistent with reported changes in cellular function in higher-yielding cows fed TMR (Kehrli and Goff, 1989; Kehrli et al., 1989; Detilleux et al., 1995). The current interpretation of the transcription results supports the hypothesis of a change in neutrophil function during the transition period that is likely a normal adaptation to calving. Collectively, the data indicate changes to the inflammatory response, the antimicrobial capacity, cellular adhesion and metabolism, and the developmental maturity of the circulating population of neutrophils during the peripartum period. For example, gene expression of cytokines and cytokine receptors, adhesion proteins, and genes involved in apoptosis were differentially expressed over the transition period. Furthermore, the transcription profiles indicate changes in the maturation state of neutrophils around the time of calving. It is conceivable that these changes may be associated with peripartum neutrophil dysfunction and the associated increase in incidence of infectious disease during this period (Mallard et al., 1998). 


\section{Inflammation and the Inflammatory Response}

The inflammatory state of neutrophils was altered at calving, a response similar to that observed during acute inflammation. Genes involved in inflammation and mediation of the inflammatory response, for example those for cytokines, TLR, and the MHC class II molecule $B O L A-D R A$, were differentially expressed over the transition period. Consistent with an inflammatory state around calving is the increase in plasma IL-6 and haptoglobin, indicating activation of the acute phase response at calving and in the early postpartum (Sordillo and Aitken, 2009; Bossaert et al., 2012). At calving, gene expression of TLR2 and IL6 was increased and BOLA-DRA decreased, comparable to the neutrophil response to an intramammary infection challenge (Moyes et al., 2010b). This gene expression profile is also exhibited in leukocytes isolated from postpartum grazing cows during an in vitro challenge with staphylococcal enterotoxin B and LPS (Heiser et al., 2015) and in response to postpartum subclinical endometritis (Walker et al., 2015). Parturition allows entry of pathogens into the uterus, thereby activating the immune response (Sheldon and Dobson, 2004). Neutrophils have a dual role in this response: destroying invading pathogens and maintaining an appropriate level of inflammation (Kehrli and Goff, 1989). This dual response must be balanced to ensure neutrophils retain the ability to destroy invading pathogens while avoiding detrimental inflammation. The extent of this response varies considerably between individual cows (Heiser et al., 2015), suggesting that some individuals are more susceptible to infectious disease than others.

Decreased expression of BOLA-DRA on the day of calving could infer a change in the interaction of neutrophils with the adaptive immune response. This is consistent with the reported decrease in MHC-II populations immediately postcalving in whole-blood leukocytes (Van Kampen and Mallard, 1997). Gene expression profiles from circulating neutrophils over the transition period are indicative of a change in their inflammatory phenotype on the day of calving. This change is likely a normal adaptation to parturition that can affect the inflammatory response of neutrophils and, in some individuals, increase susceptibility to infection.

\section{Expression of Antimicrobial Peptides}

Expression of genes encoding antimicrobial peptides (DEFB1, DEFB10,BNBD4, and LAP) in circulating neutrophils was upregulated on the day of calving, indicating an increase in the antimicrobial capability of neutrophils in response to parturition. Antimicrobial peptides, such as $\beta$-defensins, are cytotoxic to pathogenic microorganisms and are expressed in bovine

Table 3. Metabolite results over transition period; results are presented as LSM with standard error of the difference (SED) and significance of week $(P$ value $)$

\begin{tabular}{|c|c|c|c|c|c|c|c|c|}
\hline \multirow[b]{2}{*}{ Parameter $^{1}$} & \multirow[b]{2}{*}{ Units } & \multicolumn{5}{|c|}{ Time relative to parturition (d 0 ) } & \multirow[b]{2}{*}{ SED } & \multirow{2}{*}{$\frac{P \text {-value }}{\text { Week }}$} \\
\hline & & $-1 \mathrm{wk}$ & d 0 & $1 \mathrm{wk}$ & $2 \mathrm{wk}$ & $4 \mathrm{wk}$ & & \\
\hline \multicolumn{9}{|l|}{ Metabolites } \\
\hline Total protein & $\mathrm{g} / \mathrm{L}$ & $68.58^{\mathrm{c}}$ & $70.67^{\mathrm{b}}$ & $68.31^{\mathrm{c}}$ & $70.39^{\mathrm{bc}}$ & $73.44^{\mathrm{a}}$ & 0.77 & $<0.01$ \\
\hline Albumin & $\mathrm{g} / \mathrm{L}$ & $35.54^{\mathrm{b}}$ & $36.84^{\mathrm{a}}$ & $35.26^{\mathrm{b}}$ & $35.14^{\mathrm{b}}$ & $35.57^{\mathrm{b}}$ & 0.42 & $<0.01$ \\
\hline Globulin & $\mathrm{g} / \mathrm{L}$ & $33.03^{\mathrm{c}}$ & $33.82^{\mathrm{bc}}$ & $33.11^{\mathrm{c}}$ & $35.24^{\mathrm{b}}$ & $37.87^{\mathrm{a}}$ & 0.56 & $<0.01$ \\
\hline Albumin:Globulin & & $1.10^{\mathrm{a}}$ & $1.11^{\mathrm{a}}$ & $1.09^{\mathrm{a}}$ & $1.02^{\mathrm{b}}$ & $0.95^{\mathrm{c}}$ & 0.02 & $<0.01$ \\
\hline NEFA & $\mathrm{mmol} / \mathrm{L}$ & $0.66^{\mathrm{bc}}$ & $0.55^{\mathrm{c}}$ & $1.07^{\mathrm{a}}$ & $0.76^{\mathrm{b}}$ & $0.56^{\mathrm{c}}$ & 0.07 & $<0.01$ \\
\hline Haptoglobin & $\mathrm{ng} / \mathrm{mL}$ & $3.12^{\mathrm{c}}$ & $4.20^{\mathrm{a}}$ & $3.71^{\mathrm{b}}$ & $3.60^{\mathrm{bc}}$ & $3.37^{\mathrm{c}}$ & 0.11 & $<0.01$ \\
\hline Cholesterol & $\mathrm{m} M$ & $3.32^{\mathrm{ab}}$ & $3.30^{\mathrm{b}}$ & $3.26^{\mathrm{b}}$ & $3.30^{\mathrm{b}}$ & $3.40^{\mathrm{a}}$ & 0.04 & $<0.01$ \\
\hline Liver TAG & $\%$ & $0.39^{\mathrm{b}}$ & & $0.65^{\mathrm{a}}$ & $0.70^{\mathrm{a}}$ & $0.67^{\mathrm{a}}$ & 0.02 & $<0.01$ \\
\hline \multicolumn{9}{|l|}{ Cytokines } \\
\hline IL-1 $\beta$ & $\mu \mathrm{g} / \mathrm{mL}$ & $1.34^{\mathrm{b}}$ & $1.35^{\mathrm{b}}$ & $1.51^{\mathrm{a}}$ & $1.46^{\mathrm{a}}$ & $1.24^{\mathrm{c}}$ & 0.03 & $<0.01$ \\
\hline IL-6 & $\mathrm{ng} / \mathrm{mL}$ & $2.48^{\mathrm{c}}$ & $3.37^{\mathrm{a}}$ & $3.08^{\mathrm{b}}$ & $2.50^{\mathrm{c}}$ & $2.26^{\mathrm{d}}$ & 0.07 & $<0.01$ \\
\hline $\mathrm{Ca}$ & $\mathrm{mmol} / \mathrm{L}$ & $0.50^{\mathrm{b}}$ & $0.48^{\mathrm{c}}$ & $0.51^{\mathrm{a}}$ & $0.52^{\mathrm{a}}$ & & 0.01 & $<0.01$ \\
\hline
\end{tabular}

${ }^{\mathrm{a}-\mathrm{c}}$ Superscript letters denote results of Tukey's $t$-test for pairwise comparisons between weeks; time points with at least one common letter, for each parameter, do not differ significantly $(P>0.05)$ and those without at least one common letter differ significantly $(P<0.05)$.

${ }^{1}$ Metabolites BHB, nonesterified fatty acids (NEFA), aspartate transaminase (AST), haptoglobin, cytokines, and reactive oxygen species (ROS) are presented as $\log _{10}$ transformed. 
neutrophils (Savoini et al., 1984; Lai and Gallo, 2009; Meade et al., 2014). Expression of defensins occurs during myelopoiesis and mature peptides are packaged into neutrophilic granules (Yount et al., 1995). Defensins are constitutively expressed in neutrophils. However, expression can be induced in a variety of epithelial tissues during infection; for example, tracheal antimicrobial peptide (encoded by TAP) in ciliated respiratory epithelium, lingual antimicrobial peptide (encoded by the $L A P$ gene) in epithelium of mammary gland alveoli (Diamond et al., 1996, 2000; Russell et al., 1996), and $\beta$-defensins in uterine tissue (Walker et al., 2015). Furthermore, $\beta$-defensin expression can be stimulated with LPS in bovine monocytes (Merriman et al., 2015). Defensins play an important role in innate immune responses and the reported transcription profile during the calving period in this study likely reflects the host response to damaged tissue inflammatory signals and the inevitable increased exposure of internal epithelial surfaces to potential pathogenic and nonpathogenic microorganisms.

\section{Adhesion and Extravasation}

The ability of neutrophils to exit the blood and enter infected tissue via chemotaxis, a property crucial for clearance of an infection, appears to be reduced during the weeks immediately following parturition. Parturition altered expression of integrins, extracellular matrix adhesion proteins, and matrix metalloproteinases and expression remained inconsistent postcalving in the current study. Experimental models of infection have demonstrated that the efficient influx of leukocytes into tissues is related to outcome of the infection (Hill, 1981; Burvenich et al., 1994; Van Werven et al., 1997). Initial attachment and rolling of neutrophils along blood vessel endothelium is mediated by selectin molecules (L-selectin; SELL) and the ability of neutrophils to migrate out of blood vessels is reliant on integrin molecules and extracellular matrix binding proteins. Inhibition of integrin function highlights the importance of these proteins for successful trans-endothelial migration (Furie et al., 1991; Ding et al., 1999); in fact, recurrent bacterial infections is a common feature of mutations in genes of the adhesion cascade that result in leukocyte adhesion deficiency syndromes (Schmidt et al., 2013). The evident change in SELL expression in the grazing cows described here is consistent with previous experiments in TMR-fed cows (Lee and Kehrli, 1998). Those authors used flow cytometry and demonstrated decreased L-selectin and CD18 (encoded by the ITGB2 gene) expression on neutrophils $24 \mathrm{~h}$ postparturition relative to day of calving. The differential expression patterns of the integrin genes presented here indicate possible changes to the adhesion specificity of neutrophils (Loike et al., 1991) and provides evidence for a change in the population of neutrophils at different maturation states over the transition period (Ingalls and Golenbock, 1995). Evidence exists that subpopulations of neutrophils differ in the expression of adhesion molecules, thereby affecting their response to inflammatory stimuli (chemotaxis and extravasation; Kamp et al., 2012). The changes in expression of adhesion proteins and altered adhesion specificity of neutrophils demonstrated in our study is likely to have a detrimental effect on the neutrophil response to inflammatory stimuli and, as a result, may increase susceptibility to infection in the weeks immediately postcalving.

\section{Maturation State}

The transcription profiles from our study are indicative of an increase in immature neutrophils on the day of calving, likely due to the inflammatory nature of parturition. Expression results indicate that an increase is likely in the number of immature cells at the band or promyelocyte stage of maturation on the day of calving, as well as decreased expression of FCGR3A, changes in expression of adhesion molecules, and an increase in neutrophil collagenase $(M M P 8)$ and gelatinase $(M M P 9)$. Decreased protein expression of Fc $\gamma \mathrm{RIII}$ (FCGR3A) is associated with immature neutrophils at the band stage, as well as reduced cellular function (Pillay et al., 2010). Furthermore, there is differential expression of adhesion molecules depending on the maturation state of neutrophils; for example, mature neutrophils express the Mac-1 complex (CD11b/CD18; ITGAM/ITGB2) over CD11c/CD18; ITGAX/ITGB2 (Ingalls and Golenbock, 1995). According to the study by Pillay et al. (2010), distinct neutrophil subsets exist within circulating populations with unique cytokine and chemokine production. Shifts in the neutrophil population over the transition period could provide the mechanism for altered neutrophil function and provides an explanation for the unique cytokine expression signature on the day of calving. Systemic inflammation or periods of stress causes neutrophil egress from the bone marrow and results in increased immature neutrophils in circulation (Van Merris et al., 2002); this has been confirmed by flow cytometric and morphological investigation following LPS treatment in humans (Brown et al., 1989) and cows (Prin-Mathieu et al., 2002). Induction of parturition is an inflammatory event (Van Engelen et al., 2009) and neutrophil numbers increase up to parturition in dairy cows, followed by an increase in immature (band) cells in circulation (Detilleux et al., 1995). Additional supporting evidence of an increase in immature neutrophils in circulation comes from the 
increased expression of $M M P 8$ and $M M P 9$ on the day of calving in the current study. These peptides are usually packaged in granules in an inactive form to be activated after exocytosis (Faurschou and Borregaard, 2003). Therefore, an increase in mRNA transcripts may indicate that fewer transcripts are in a tertiary protein structure packaged within granules in early lactation in the current experimental model; however, this would need to be confirmed by investigating granule formation and expression of MMP8 and -9 at the protein level. Data supports an increase in immature neutrophils in circulation on the day of calving, which may compromise neutrophil function systemically and the ability of the neutrophil to neutralize invading pathogens.

Further evidence for a shift in the maturation state of circulating neutrophils around calving is the differential expression of genes involved in apoptosis. We propose from our results that the decreased expression of proapoptotic genes (e.g., CASP8, KIT, and FASLG; Theilgaard-Mönch et al., 2004; Croker et al., 2011), with concomitant increase in expression of antiapoptotic gene MCL1 (Dzhagalov et al., 2007), are indicative of an increased neutrophil lifespan postcalving compared with the precalving state. Neutrophil apoptosis is tightly regulated (Luo and Loison, 2008) and a delay in apoptosis may be advantageous at the beginning of an infection, as the onset of apoptosis leads to functional impairment (Whyte et al., 1993). Supporting evidence of a change in neutrophil apoptosis during the periparturient period was also reported by Chang et al. (2004). Their results indicate that the peripartum rise in glucocorticoids reduces Fas-induced apoptosis. Similarly, our results demonstrate decreased expression of FASLG on the day of calving, lending support to the conclusion that decreased apoptosis in response to glucocorticoids (e.g., cortisol) is a mechanism for increasing lifespan of neutrophils around parturition (Chang et al., 2004). Investigation of additional Bcl-2-related targets (e.g., $B A D, B A K$, and $B A X$ ) involved in apoptosis may provide further insight into neutrophil apoptotic regulation over the transition period. The data presented here does not conclusively confirm increased lifespan of neutrophils on the day of calving; however, the transcription profile of genes involved in apoptosis is altered during the transition period, which may support a reprogramming of key apoptotic regulators in response to high cortisol concentrations at parturition.

\section{Cellular Metabolism}

Altered expression of transcription factors indicates changes to the control of inflammatory networks over the transition period. The expression of PPARD and
$R X R A$ are decreased 1 wk postcalving compared with on the day of calving, which is in agreement with results demonstrated by Osorio et al. (2013). Additional evidence of activation of the PPAR network on the day of calving is (1) the increased expression of genes involved in leukotriene synthesis (ALOX5AP and PLA2G4A) and (2) decreased expression of the gene encoding the glucose transporter (SLC2A1) with increased expression of the gene encoding lactate dehydrogenase $\mathrm{A}(L D H A)$, an enzyme involved in glycolysis. These results are consistent with a change in the PPAR-RXRA inflammatory network and likely influenced by a change in the utilization of arachidonic acid for prostaglandin and eicosanoid production, which can activate the PPAR network (Osorio et al., 2013; Zhou et al., 2015). Arachidonic acid, the precursor of leukotrienes, increases in neutrophils isolated under inflammatory conditions (Klock and Pieprzyk, 1979). Leukotrienes derived from oxidation of arachidonic acid (e.g., leukotriene $\mathrm{B}_{4}$ ) induce PPAR expression; this stimulates production of the anti-inflammatory cytokine IL-10, which ensures chronic inflammation does not occur (Kuehl and Egan, 1980; Buckley et al., 2014). The reduced expression of SLC2A1 (GLUT1) may be a reflection of increased glucose requirements by the mammary gland (Bell, 1995) or a response to fetal cortisol release at parturition (Preisler et al., 2000). In this study we did not measure blood glucose concentrations; however, previous work suggests an increase on the day of calving (Roche, 2007). Neutrophils rely on glucose uptake (via GLUT1) and glycolysis for antibactericidal effects and phagocytosis; therefore, if cellular metabolism is perturbed, neutrophil function will be affected (Borregaard and Herlin, 1982; Weisdorf et al., 1982). It is likely that the altered cellular metabolism in response to parturition dampens the inflammatory response of neutrophils during the transition period and may prevent unnecessary excessive inflammation.

\section{CONCLUSIONS}

Our results indicate an altered inflammatory state in neutrophils during the transition period, providing additional evidence of changes in neutrophil function in response to the calving event and the homeorhetic adaptation to lactation. The gene expression profiles in grazing dairy cows align with current research indicating neutrophil dysfunction in conventional housing systems. The changes in the inflammatory response likely increase the susceptibility of dairy cows to infection during the peripartum period. The reported gene expression changes may be associated with altered neutrophil populations favoring an immature phenotype; 
however, further investigation will provide greater comprehension and possible mechanisms to shift populations potentially alleviating immunological strain.

\section{ACKNOWLEDGMENTS}

The authors acknowledge farm staff (Scott Farm, DairyNZ) and, in particular, Jason Philips (farm manager). We also wish to acknowledge DairyNZ technical staff, Stu Morgan, Kate Watkins, Hamish Hodgson, and Chris Roach, for technical support and assistance with animal handling and sample collection. We acknowledge the statistical analysis and advice of Barbara Kuhn-Sherlock (DairyNZ) and the technical assistance of Daniel Verdon (School of Biological Sciences and Maurice Wilkins Centre for Molecular Biodiscovery, University of Auckland). This work was supported by funding from New Zealand dairy farmers through DairyNZ Inc. (RD1403) and the Ministry of Business, Innovation and Employment, Wellington, New Zealand (DRCX1201).

\section{REFERENCES}

Andersen, C. L., J. L. Jensen, and T. F. Ørntoft. 2004. Normalization of real-time quantitative reverse transcription-PCR data: A model-based variance estimation approach to identify genes suited for normalization, applied to bladder and colon cancer data sets. Cancer Res. 64:5245-5250.

Bell, A. W. 1995. Regulation of organic nutrient metabolism during transition from late pregnancy to early lactation. J. Anim. Sci. 73:2804-2819.

Borregaard, N., and T. Herlin. 1982. Energy metabolism of human neutrophils during phagocytosis. J. Clin. Invest. 70:550-557. http://dx.doi.org/10.1172/JCI110647.

Bossaert, P., E. Trevisi, G. Opsomer, G. Bertoni, S. De Vliegher, and J. L. M. R. Leroy. 2012. The association between indicators of inflammation and liver variables during the transition period in high-yielding dairy cows: An observational study. Vet. J. 192:222225. http://dx.doi.org/10.1016/j.tvjl.2011.06.004.

Brown, C. C., H. L. Malech, and J. I. Gallin. 1989. Intravenous endotoxin recruits a distinct subset of human neutrophils, defined by monoclonal antibody 31D8, from bone marrow to the peripheral circulation. Cell. Immunol. 123:294-306. http://dx.doi. org/10.1016/0008-8749(89)90290-6.

Buckley, C. D., D. W. Gilroy, and C. N. Serhan. 2014. Proresolving lipid mediators and mechanisms in the resolution of acute inflammation. Immunity 40:315-327. /http://dx.doi.org/10.1016/j. immuni.2014.02.009.

Burton, J. L., M. E. Kehrli, S. Kapil, and L. Horst. 1995. Regulation of L-selectin and CD18 on bovine neutrophils by glucocorticoids: Effects of cortisol and dexamethasone. J. Leukoc. Biol. 57:317-325.

Burton, J. L., S. A. Madsen, L.-C. Chang, P. S. D. Weber, K. R. Buckham, R. van Dorp, M.-C. Hickey, and B. Earley. 2005. Gene expression signatures in neutrophils exposed to glucocorticoids: A new paradigm to help explain "neutrophil dysfunction" in parturient dairy cows. Vet. Immunol. Immunopathol. 105:197-219. http://dx.doi.org/10.1016/j.vetimm.2005.02.012.

Burvenich, C., M. J. Paape, A. W. Hill, A. J. Guidry, R. H. Miller, R. Heyneman, W. D. J. Kremer, and A. Brand. 1994. Role of the neutrophil leucocyte in the local and systemic reactions during experimentally induced $E$. coli mastitis in cows immediately after calving. Vet. Q. 16:45-50. http://dx.doi.org/10.1080/01652176.19 94.9694482 .
Chang, L.-C., S. A. Madsen, T. Toelboell, P. S. D. Weber, and J. L. Burton. 2004. Effects of glucocorticoids on Fas gene expression in bovine blood neutrophils. J. Endocrinol. 183:569-583. http:// dx.doi.org/10.1677/joe.1.05822.

Compton, C. W. R., C. Heuer, K. Parker, and S. McDougall. 2007. Epidemiology of mastitis in pasture-grazed peripartum dairy heifers and its effects on productivity. J. Dairy Sci. 90:4157-4170. http://dx.doi.org/10.3168/jds.2006-880.

Croker, B. A., J. A. O’Donnell, C. J. Nowell, D. Metcalf, G. Dewson, K. J. Campbell, K. L. Rogers, Y. Hu, G. K. Smyth, J.-G. Zhang, M. White, K. Lackovic, L. H. Cengia, L. A. O'Reilly, P. Bouillet, S. Cory, A. Strasser, and A. W. Roberts. 2011. Fas-mediated neutrophil apoptosis is accelerated by Bid, Bak, and Bax and inhibited by Bcl-2 and Mcl-1. Proc. Natl. Acad. Sci. USA 108:13135-13140. http://dx.doi.org/10.1073/pnas.1110358108.

Detilleux, J. C., M. E. Kehrli, J. R. Stabel, A. E. Freeman, and D. H. Kelley. 1995. Study of immunological dysfunction in periparturient Holstein cattle selected for high and average milk production. Vet. Immunol. Immunopathol. 44:251-267.

Diamond, G., V. Kaiser, J. Rhodes, J. P. Russell, and C. L. Bevins. 2000. Transcriptional regulation of $\beta$-defensin gene expression in tracheal epithelial cells. Infect. Immun. 68:113-119.

Diamond, G., J. P. Russell, and C. L. Bevins. 1996. Inducible expression of an antibiotic peptide gene in lipopolysaccharide-challenged tracheal epithelial cells. Proc. Natl. Acad. Sci. USA 93:5156-5160. http://dx.doi.org/10.1073/pnas.93.10.5156.

Ding, Z. M., J. E. Babensee, S. I. Simon, H. Lu, J. L. Perrard, D. C. Bullard, X. Y. Dai, S. K. Bromley, M. L. Dustin, M. L. Entman, C. W. Smith, and C. M. Ballantyne. 1999. Relative contribution of LFA-1 and Mac-1 to neutrophil adhesion and migration. J. Immunol. 163:5029-5038.

Dzhagalov, I., A. St. John, and Y. W. He. 2007. The antiapoptotic protein Mcl-1 is essential for the survival of neutrophils but not macrophages. Blood 109:1620-1626. http://dx.doi.org/10.1182/ blood-2006-03-013771.

Faurschou, M., and N. Borregaard. 2003. Neutrophil granules and secretory vesicles in inflammation. Microbes Infect. 5:1317-1327. http://dx.doi.org/10.1016/j.micinf.2003.09.008.

Furie, M. B., M. C. Tancinco, and C. W. Smith. 1991. Monoclonal antibodies to leukocyte integrins CD11a/CD18 and CD11b/CD18 or intercellular adhesion molecule-1 inhibit chemoattractantstimulated neutrophil transendothelial migration in vitro. Blood 78:2089-2097.

Goff, J. P., and R. L. Horst. 1997. Physiological changes at parturition and their relationship to metabolic disorders. J. Dairy Sci. 80:12601268. http://dx.doi.org/10.3168/jds.S0022-0302(97)76055-7.

Graugnard, D. E., M. Bionaz, E. Trevisi, K. M. Moyes, J. L. SalakJohnson, R. L. Wallace, J. K. Drackley, G. Bertoni, and J. J. Loor. 2012. Blood immunometabolic indices and polymorphonuclear neutrophil function in peripartum dairy cows are altered by level of dietary energy prepartum. J. Dairy Sci. 95:1749-1758. http:// dx.doi.org/10.3168/jds.2011-4579.

Grummer, R. R. 1995. Impact of changes in organic nutrient metabolism on feeding the transition dairy cow. J. Anim. Sci. 73:28202833.

Hammon, D. S., and J. P. Goff. 2006. Immune function and energy status in Holstein cows with uterine infections. Pages 29-36 in Mid-South Ruminant Nutrition Conference, Arlington, TX. Texas Animal Nutrition Council, TX.

Heiser, A., A. Mccarthy, N. Wedlock, S. Meier, J. Kay, C. Walker, M. A. Crookenden, M. D. Mitchell, S. Morgan, K. Watkins, J. J. Loor, and J. R. Roche. 2015. Grazing dairy cows had decreased interferon- $\gamma$, tumor necrosis factor, and interleukin-17, and increased expression of interleukin-10 during the first week after calving. J. Dairy Sci. 98:937-946. http://dx.doi.org/10.3168/ jds.2014-8494.

Hill, A. W. 1981. Factors influencing the outcome of Escherichia coli mastitis in the dairy cow. Res. Vet. Sci. 31:107-112.

Ingalls, R. R., and D. T. Golenbock. 1995. CD11c/CD18, a transmembrane signaling receptor for lipopolysaccharide. J. Exp. Med. $181: 1473-1479$. 
Ingvartsen, K. L. 2006. Feeding- and management-related diseases in the transition cow. Anim. Feed Sci. Technol. 126:175-213. http:// dx.doi.org/10.1016/j.anifeedsci.2005.08.003.

Kamp, V. M., J. Pillay, J.-W. J. Lammers, P. Pickkers, L. H. Ulfman, and L. Koenderman. 2012. Human suppressive neutrophils CD16bright/CD62Ldim exhibit decreased adhesion. J. Leukoc. Biol. 92:1011-1020. /http://dx.doi.org/10.1189/jlb.0612273.

Kehrli, M. E., and J. P. Goff. 1989. Periparturient hypocalcemia in cows: Effects on peripheral blood neutrophil and lymphocyte function. J. Dairy Sci. 72:1188-1196. http://dx.doi.org/10.3168/jds. S0022-0302(89)79223-7.

Kehrli, M. E., B. J. Nonnecke, and J. A. Roth. 1989. Alterations in bovine neutrophil function during the periparturient period. Am. J. Vet. Res. 50:207-214.

Klock, J. C., and J. K. Pieprzyk. 1979. Cholesterol, phospholipids, and fatty acids of normal immature neutrophils: Comparison with acute myeloblastic leukemia cells and normal neutrophils. J. Lipid Res. 20:908-911.

Kolver, E. S., and L. D. Muller. 1998. Performance and nutrient intake of high producing Holstein cows consuming pasture or a total mixed ration. J. Dairy Sci. 81:1403-1411. http://dx.doi. org/10.3168/jds.S0022-0302(98)75704-2.

Kuehl, F.A., and R.W. Egan. 1980. Prostaglandins, arachidonic acid, and inflammation. Science 210:978-984.

Lai, Y., and R. L. Gallo. 2009. AMPed up immunity: How antimicrobial peptides have multiple roles in immune defense. Trends Immunol. 30:131-141. http://dx.doi.org/10.1016/j.it.2008.12.003.

LeBlanc, S. J., K. D. Lissemore, D. F. Kelton, T. F. Duffield, and K. E. Leslie. 2006. Major advances in disease prevention in dairy cattle. J. Dairy Sci. 89:1267-1279. http://dx.doi.org/10.3168/jds. S0022-0302(06)72195-6.

Lee, E. K., and M. E. Kehrli. 1998. Expression of adhesion molecules on neutrophils of periparturient cows and neonatal calves. Am. J. Vet. Res. 59:37-43.

Loike, J. D., B. Sodeik, L. Cao, S. Leucona, J. Weitz, P. A. Detmers, S. D. Wright, and S. C. Silverstein. 1991. CD11c/CD18 on neutrophils recognizes a domain at the $\mathrm{N}$ terminus of the $\mathrm{A} \alpha$ chain of fibrinogen. Proc. Natl. Acad. Sci. USA 88:1044-1048.

Luo, H. R., and F. Loison. 2008. Constitutive neutrophil apoptosis: Mechanisms and regulation. Am. J. Hematol. 83:288-295. http:// dx.doi.org/10.1002/ajh.21078.

Madsen, S. A., L.-C. Chang, M.-C. Hickey, G. J. M. Rosa, P. M. Coussens, and J. L. Burton. 2004. Microarray analysis of gene expression in blood neutrophils of parturient cows. Physiol. Genomics 16:212-221. http://dx.doi.org/10.1152/physiolgenomics.00121.2003.

Mallard, B. A., J. C. Dekkers, M. J. Ireland, K. E. Leslie, S. Sharif, C. Lacey Vankampen, L. Wagter, and B. N. Wilkie. 1998. Alteration in immune responsiveness during the peripartum period and its ramification on dairy cow and calf health. J. Dairy Sci. 81:585595. http://dx.doi.org/10.3168/jds.S0022-0302(98)75612-7.

Meade, K. G., P. Cormican, F. Narciandi, A. Lloyd, and C. O'Farrelly 2014. Bovine $\beta$-defensin gene family: Opportunities to improve animal health? Physiol. Genomics 46:17-28. http://dx.doi. org/10.1152/physiolgenomics.00085.2013.

Merriman, K. E., M. F. Kweh, J. L. Powell, J. D. Lippolis, and C. D. Nelson. 2015. Multiple $\beta$-defensin genes are upregulated by the vitamin D pathway in cattle. J. Steroid Biochem. Mol. Biol. 154:120-129. http://dx.doi.org/10.1016/j.jsbmb.2015.08.002.

Ministry of Primary Industries. 1999. New Zealand Animal Welfare Act. In Part 6. Use of animals in research, testing and teaching. Accessed Jan. 24, 2015. http://www.biosecurity.govt.nz/ legislation/animal-welfare-act/index.htm.

Moyes, K. M., J. K. Drackley, D. E. Morin, and J. J. Loor. 2010a. Greater expression of TLR2, TLR4, and IL6 due to negative energy balance is associated with lower expression of HLA-DRA and HLA-A in bovine blood neutrophils after intramammary mastitis challenge with Streptococcus uberis. Funct. Integr. Genomics 10:53-61

Moyes, K. M., J. K. Drackley, D. E. Morin, S. L. Rodriguez-Zas, R. E. Everts, H. A. Lewin, and J. J. Loor. 2010b. Mammary gene expression profiles during an intramammary challenge reveal potential mechanisms linking negative energy balance with impaired immune response. Physiol. Genomics 41:161-170. http://dx.doi. org/10.1152/physiolgenomics.00197.2009.

Moyes, K. M., D. E. Graugnard, M. J. Khan, M. Mukesh, and J. J. Loor. 2014. Postpartal immunometabolic gene network expression and function in blood neutrophils are altered in response to prepartal energy intake and postpartal intramammary inflammatory challenge. J. Dairy Sci. 97:2165-2177. http://dx.doi.org/10.3168/ jds.2013-7433

Osorio, J. S., E. Trevisi, M. A. Ballou, G. Bertoni, J. K. Drackley, and J. J. Loor. 2013. Effect of the level of maternal energy intake prepartum on immunometabolic markers, polymorphonuclear leukocyte function, and neutrophil gene network expression in neonatal Holstein heifer calves. J. Dairy Sci. 96:3573-3587.

Østergaard, S., M. G. G. Chagunda, N. C. Friggens, T. W. Bennedsgaard, and I. C. Klaas. 2005. A stochastic model simulating pathogen-specific mastitis control in a dairy herd. J. Dairy Sci. 88:42434257. http://dx.doi.org/10.3168/jds.S0022-0302(05)73111-8.

Overton, T. R., and M. R. Waldron. 2004. Nutritional management of transition dairy cows: Strategies to optimize metabolic health J. Dairy Sci. 87:E105-E119. http://dx.doi.org/10.3168/jds.S00220302(04)70066-1.

Pillay, J., B. P. Ramakers, V. M. Kamp, A. L. T. Loi, S. W. Lam, F. Hietbrink, L. P. Leenen, A. T. Tool, P. Pickkers, and L. Koenderman. 2010. Functional heterogeneity and differential priming of circulating neutrophils in human experimental endotoxemia. J Leukoc. Biol. 88:211-220. http://dx.doi.org/10.1189/jlb.1209793.

Preisler, M. T., P. S. D. Weber, R. J. Tempelman, R. J. Erskine, H. Hunt, and J. L. Burton. 2000. Glucocorticoid receptor downregulation in neutrophils of periparturient cows. Am. J. Vet. Res. 61:14-19.

Prin-Mathieu, C., Y. Le Roux, G. C. Faure, F. Laurent, M. C. Bene, and F. Moussaoui. 2002. Enzymatic activities of bovine peripheral blood leukocytes and milk polymorphonuclear neutrophils during intramammary inflammation caused by lipopolysaccharide. Clin. Diagn. Lab. Immunol. 9:812-817. http://dx.doi.org/10.1128/ CDLI.9.4.812-817.2002.

Roche, J. R. 2007. Milk production responses to pre- and postcalving dry matter intake in grazing dairy cows. Livest. Sci. 110:12-24. http://dx.doi.org/10.1016/j.livsci.2006.08.016.

Roche, J. R. 2012. Avoiding metabolic diseases around calving. DairyNZ Tech. Ser. 10:13-18. Accessed Jan. 16, 2015. http:// www.dairynz.co.nz/media/424974/technical_series_june_2012. pdf\#page $=13$.

Roche, J. R., P. G. Dillon, C. R. Stockdale, L. H. Baumgard, and M. J. VanBaale. 2004. Relationships among international body condition scoring systems. J. Dairy Sci. 87:3076-3079. http://dx.doi. org/10.3168/jds.S0022-0302(04)73441-4.

Roche, J. R., S. Meier, A. Heiser, M. D. Mitchell, C. G. Walker, M. A. Crookenden, M. V. V. Riboni, J. J. Loor, and J. K. Kay. 2015 Effects of precalving body condition score and prepartum feeding level on production, reproduction, and health parameters in pasture-based transition dairy cows. J. Dairy Sci. 98:7164-7182. http://dx.doi.org/10.3168/jds.2014-9269.

Russell, J. P., G. Diamond, A. P. Tarver, T. F. Scanlin, and C. L. Bevins. 1996. Coordinate induction of two antibiotic genes in tracheal epithelial cells exposed to the inflammatory mediators LPS and tumor necrosis factor. Infect. Immun. 64:1565-1568.

Saraiva, M., and A. O'Garra. 2010. The regulation of IL-10 production by immune cells. Nat. Rev. Immunol. 10:170-181.

Savoini, A., R. Marzari, L. Dolzani, D. Serranò, G. Graziosi, R. Gennaro, and D. Romeo. 1984. Wide-spectrum antibiotic activity of bovine granulocyte polypeptides. Antimicrob. Agents Chemother. 26:405-407. http://dx.doi.org/10.1128/AAC.26.3.405.

Schmidt, S., M. Moser, and M. Sperandio. 2013. The molecular basis of leukocyte recruitment and its deficiencies. Mol. Immunol. 55:49-58. http://dx.doi.org/10.1016/j.molimm.2012.11.006.

Sheldon, I. M., and H. Dobson. 2004. Postpartum uterine health in cattle. Anim. Reprod. Sci. 82-83:295-306. http://dx.doi. org/10.1016/j.anireprosci.2004.04.006. 
Sordillo, L. M., and S. L. Aitken. 2009. Impact of oxidative stress on the health and immune function of dairy cattle. Vet. Immunol. Immunopathol. 128:104-109. http://dx.doi.org/10.1016/j. vetimm.2008.10.305.

Theilgaard-Mönch, K., S. Knudsen, P. Follin, and N. Borregaard. 2004. The transcriptional activation program of human neutrophils in skin lesions supports their important role in wound healing. J. Immunol. 172:7684-7693. http://dx.doi.org/10.4049/ jimmunol.172.12.7684.

Van Engelen, E., M. W. de Groot, V. N. A. Breeveld-Dwarkasing, M. E. Everts, G. C. van der Weyden, M. A. M. Taverne, and V. P. M. G. Rutten. 2009. Cervical ripening and parturition in cows are driven by a cascade of pro-inflammatory cytokines. Reprod. Domest. Anim. 44:834-841. http://dx.doi.org/10.1111/j.14390531.2008.01096.x.

Van Kampen, C., and B. A. Mallard. 1997. Effects of peripartum stress and health on circulating bovine lymphocyte subsets. Vet. Immunol. Immunopathol. 59:79-91. http://dx.doi.org/10.1016/S01652427(97)00069-X.

Van Merris, V., E. Meyer, and C. Burvenich. 2002. Functional maturation during bovine granulopoiesis. J. Dairy Sci. 85:2859-2868. http://dx.doi.org/10.3168/jds.S0022-0302(02)74373-7.

Van Werven, T., E.N. Noordhuizen-Stassen, A.J. Daemen, Y.H. Schukken, A. Brand, and C. Burvenich. 1997. Preinfection in vitro chemotaxis, phagocytosis, oxidative burst, and expression of CD11/CD18 receptors and their predictive capacity on the outcome of mastitis induced in dairy cows with Escherichia coli. J. Dairy Sci. 80:67-74.
Vandesompele, J., K. De Preter, F. Pattyn, B. Poppe, N. Van Roy, A. De Paepe, and F. Speleman. 2002. Accurate normalization of real-time quantitative RT-PCR data by geometric averaging of multiple internal control genes. Genome Biol. 3:RESEARCH0034.

Walker, C. G., S. Meier, H. Hussein, S. McDougall, C. R. Burke, J. R. Roche, and M. D. Mitchell. 2015. Modulation of the immune system during postpartum uterine inflammation. Physiol. Genomics 47:89101. http://dx.doi.org/10.1152/physiolgenomics.00098.2014.

Weisdorf, D. J., P. R. Craddock, and S. Jacob. 1982. Glycogenolysis versus glucose transport in human granulocytes: Differential activation in phagocytosis and chemotaxis. Blood 60:888-893.

Whyte, M. K., L. C. Meagher, J. MacDermot, and C. Haslett. 1993. Impairment of function in aging neutrophils is associated with apoptosis. J. Immunol. 150:5124-5134.

Xing, Z., J. Gauldie, G. Cox, H. Baumann, M. Jordana, X. F. Lei, and M. K. Achong. 1998. IL-6 is an antiinflammatory cytokine required for controlling local or systemic acute inflammatory responses. J. Clin. Invest. 101:311-320. http://dx.doi.org/10.1172/ JCI1368.

Yount, N. Y., M. S. Wang, J. Yuan, N. Banaiee, A. J. Ouellette, and M. E. Selsted. 1995. Rat neutrophil defensins. Precursor structures and expression during neutrophilic myelopoiesis. J. Immunol. 155:4476-4484

Zhou, Z., D. P. Bu, M. V. Riboni, M. J. Khan, D. E. Graugnard, J. Luo, F. C. Cardoso, and J. J. Loor. 2015. Prepartal dietary energy level affects peripartal bovine blood neutrophil metabolic, antioxidant, and inflammatory gene expression. J. Dairy Sci. 98:54925505. http://dx.doi.org/10.3168/jds.2014-8811. 